\title{
Composition and density of bacterial biofilms determine larval settlement of the polychaete Hydroides elegans
}

\author{
Shuyi Huang, Michael G. Hadfield* \\ Kewalo Marine Laboratory, University of Hawaii, 41 Ahui Street, Honolulu, Hawaii 96813, USA
}

\begin{abstract}
Larvae of the polychaete worm Hydroides elegans settle and metamorphose in response to marine biofilms. Phylogenetic relationships among 4 marine-biofilm bacterial species identified by 16S rDNA sequences were not predictive of their inductive capacity. Two bacterial species separated by a genetic distance of $30 \%$ shared the greatest capacity for inducing metamorphosis in $H$. elegans. Two bacterial strains with only a $3 \%$ divergence in $16 \mathrm{~S}$ rRNA gene sequences were very different; one strain induced metamorphosis strongly while the other one did not. The percent of larvae that metamorphosed correlated positively with bacterial density in either natural biofilms or biofilms composed of a single bacterial species. When results of tests across 4 bacterial species were compared, the most inductive bacterial species was effective in much lower biofilm densities than weakly or non-inductive bacteria. Evidence presented here indicates that the cue that triggers settlement and metamorphosis in larvae of $H$. elegans is not unique to a single bacterial taxon and is likely to be an insoluble, surface-bound material.
\end{abstract}

KEY WORDS: Biofilm bacteria $\cdot$ Larval settlement $\cdot$ Metamorphosis $\cdot$ Hydroides elegans

\section{INTRODUCTION}

Many benthic marine invertebrates have complex life cycles that consist of 1 or more planktonic larval stages and an adult stage. The transition between the 2 phases includes settlement of the larva and its irreversible metamorphosis into the juvenile form. Transport and subsequent recruitment of larvae are essential for dispersing, colonizing new habitats and maintaining populations (Hofmann et al. 1996). For most species studied, the settlement of larvae is not random but correlates with biological, chemical and physical factors in the environment (Crisp 1974, Chia \& Rice 1978, Pawlik 1992, Hadfield \& Paul 2001). Larvae that are competent to metamorphose typically are able to remain pelagic in the water column until they encounter proper environmental cues, which may indicate suitable habitats (Hadfield 1998, 2000); exceptions are small lecithotrophic larvae that may simply exhaust their energy reserves during extended swim- ming periods, e.g. ascidian tadpoles, bryozoan coronate larvae and barnacle cyprids.

Bacterial biofilms modify both physical and chemical characteristics of substrata, and may enhance initial attachment by larvae and serve as food for juvenile and adult marine invertebrates (Decho 1990). Selective settlement on biofilms has been shown for larvae of many marine invertebrates, including the scleractinian corals Acropora willisae and A. millepora (Negri et al. 2001), the scyphomedusae Cassiopia spp. (Hofmann et al. 1996), the polychaetes Janua brasiliensis (Kirchman et al. 1982) and Pomatoceros lamarkii (Hamer et al. 2001), the bryozoan Bugula neritina (Maki et al. 1989), the oyster Crassostrea gigas (Fitt et al. 1990), the sea scallop Placopecten magellanicus (Parsons et al. 1993), the mussel Mytilus edulis (Satuito et al. 1995), the barnacles Balanus amphitrite (Wieczorek et al. 1995), Elminius modestus and Balanus perforatus (Neal \& Yule 1994), the starfish Acanthaster planci (Johnson \& Sutton 1994) and the ascidian Ciona intestinalis (Szewzyk et al. 1991). 
The dioecious, free-spawning, serpulid polychaete Hydroides elegans Haswell (1883) is a common fouling species in tropical and warm temperate bays and harbors, including those of Hawaii. In the laboratory, the planktotrophic larvae of $H$. elegans become competent to settle and metamorphose in approximately $5 \mathrm{~d}$, but do so only in the presence of a bacterial biofilm (Hadfield et al. 1994, Unabia \& Hadfield 1999). When exposed to a well-developed biofilm, a larva contacts the surface repeatedly with its apical tuft and then attaches to the surface with a sticky mucous thread secreted from its tail region (Carpizo-Ituarte \& Hadfield 1998). Immediately, it secretes a proteinaceous primary tube, within which metamorphosis proceeds, including resorption of the prototrochal cilia, elongation of its body and differentiation of the collar region. Soon after, the metamorphosing worm begins to secrete the calcareous secondary tube and develop branchial tentacles. The irreversible process of metamorphosis is completed within $12 \mathrm{~h}$ of contact with a biofilm (Carpizo-Ituarte \& Hadfield 1998).

Settlement of the larvae of Hydroides elegans requires a minimum microbial density, and the percentage of larval settlement correlates with bacterial density in natural biofilms composed of multiple bacterial species, filamentous algae, diatoms and fungi (Hadfield et al. 1994). A highly inductive biofilm can be obtained by soaking a substratum, such as a glass slide or a piece of plastic mesh, for $3 \mathrm{~d}$ or longer in flowing natural seawater in a laboratory sea table. The density of this biofilm is comparable to a 1 to $3 \mathrm{~d}$ biofilm from Pearl Harbor, Hawaii (Hadfield et al. 1994). Settlement induction is reduced or eliminated when biofilms are killed by boiling, UV irradiation, or exposure to formaldehyde, glutaraldehyde, ethanol or methanol (Unabia \& Hadfield 1999). Monospecific bacterial films have been shown to have inductive, neutral or toxic effects on larval settlement (Unabia \& Hadfield 1999). Two bacterial strains studied by Lau \& Qian (2001), Roseobacter sp. and an unidentified species in the $\alpha$-subclass Proteobacteria group, specifically induced settlement in larva of $H$. elegans; the response was reduced in the presence of streptomycin. Although the exact location where a larva of $H$. elegans permanently settles may be affected by local hydrodynamics, neither conspecific individuals nor other physical characteristics of the substratum overcome the requirement for a well-developed biofilm in stimulating the settlement process (Walters et al. 1997).

ZoBell \& Allen (1935) first proposed that bacteria on marine surfaces provide settlement cues for some macroorganisms. They noted that when clean substrata were submerged in the ocean, typically several days passed before macroorganisms started attaching to them, a period during which the dominant organ- isms found on the substrata were bacteria. Zobell \& Allen concluded that the 'delay' in attachment of macroorganisms reflected the time required to build up sufficient bacterial films on the surfaces to induce settlement of plants and animals. Many decades of subsequent research have demonstrated that responses to bacterial films vary among different types of larvae (reviewed by Hadfield \& Paul 2001). For example, larval settlement in Balanus amphitrite is inhibited by early, 1 to $3 \mathrm{~d}$, natural biofilms, but is stimulated by 12 to $18 \mathrm{~d}$ films (Wieczorek et al. 1995). By contrast, settlement intensity of Hydroides elegans correlates tightly with the density of bacterial cells in biofilms (Hadfield et al. 1994). Similarly, larvae of the polychaete Pomatoceros lamarkii discriminate among biofilms of different ages, with settlement density closely relating to the bacterial density of a biofilm (Hamer et al. 2001).

Surfaces in a natural aqueous environment are readily colonized by bacteria. The attachment of bacteria occurs at solid-liquid interfaces, and the process is controlled by the in situ characteristics of the surface. After attachment, bacteria produce numerous extracellular macromolecules that form a matrix on the substratum. These extracellular molecules serve many important functions for the biofilm bacterial communities, such as buffering against microenvironmental changes, localization of extracellular enzymes, sequestering nutrients, attachment and movement on surfaces, and protection against toxins, grazing and digestion (Decho 1990).

The effects of biofilms on recruiting marine invertebrate larvae might involve cues either released into the surrounding water (water-borne) or present on the surface of the substratum (surface-bound). Steinberg et al. (2001) argued that inducers of marine invertebrate settlement are more likely to be water-soluble primary metabolites. However, for many marine invertebrates, including most members of fouling communities that encrust piers and anchored ships, the cues are found to be large, insoluble, surface-bound molecules associated with biofilms (Hadfield \& Strathmann 1996). Among such molecules are the extracellular polysaccharides (EPS) secreted by most bacteria. EPS have been proposed as important factors in inducing larval settlement of various marine invertebrates (Mitchell \& Kirchman 1984, Szewzyk et al. 1991).

In an attempt to test the importance of EPS to the settlement of larval Hydroides elegans, we employed the bacterium Pseudoalteromonas atlantica, a common colonist of coastal marine substrata in both Atlantic and Pacific Oceans (Akagawa-Matsushita et al. 1992). Typical $P$. atlantica, the mucoid type (M), produces large quantities of EPS, which is considered to be a primary adhesive agent for cell-to-surface attachment. A 
variant of $P$. atlantica, the crenated type (C), yields less than $5 \%$ of the EPS produced by M-type cells (Bartlett et al. 1988). No differences in lipopolysaccharides or membrane proteins have been detected between the M- and C-types (Bartlett et al. 1988). Genetic analysis showed that the insertion of a $1.2 \mathrm{~kb}$ DNA sequence in the eps locus results in EPS ${ }^{-}$(C-type), whereas the excision of this sequence, reverses the phenotype to EPS $^{+}$(M-type) (Bartlett \& Silverman 1989). In the present study, larvae of $H$. elegans were exposed to biofilms composed of each of these variants of $P$. atlantica to determine whether the EPS differences might exert an effect on larval settlement.

The research described here focused on 5 aspects of the induction of settlement and metamorphosis in larvae of Hydroides elegans: (1) the phylogenetic relationships among inductive and non-inductive bacterial strains using 16S rRNA-gene sequence analyses to determine bacterial relationships; (2) the effect of bacterial cell density differences in 4 monospecific bacterial biofilms; (3) the effect of differing cell densities in biofilms formed by 1 inductive bacterial species; (4) the effect of soluble bacterial products; and (5) the effect of EPS production by a biofilm bacterium.

\section{MATERIALS AND METHODS}

Larval culture. Adult Hydroides elegans were collected throughout the year from Pearl Harbor, Hawaii, and maintained in sea tables with ambient flowing seawater at the Kewalo Marine Laboratory of the University of Hawaii at Manoa, Honolulu, HI, for no longer than $14 \mathrm{~d}$ (the ambient seawater temperature range is $\sim 23$ to $27^{\circ} \mathrm{C}$ near Honolulu). Intact adult tubes were gently broken near their apertures to induce spawning. Developmental stages were maintained at a density of 5 to 10 larvae $\mathrm{ml}^{-1}$ in $2 \mathrm{l}$ of $0.22 \mu \mathrm{m}$-filtered seawater (FSW) at room temperature $\left(22\right.$ to $\left.24^{\circ} \mathrm{C}\right)$. After $2 \mathrm{~d}$, larvae were collected on a $0.41 \mu \mathrm{m}$ mesh, transferred to fresh FSW and fed daily until they reached metamorphic competence at approximately $5 \mathrm{~d}$. Isochrysis galbana Tahitian strain was provided as food to the planktotrophic larvae at a concentration of $10^{5}$ cells ml ${ }^{-1}$.

Bacterial isolation and storage. Biofilm bacteria were sampled from a seasoned sea table at Kewalo Marine Laboratory by sterile swabs and transferred to half-strength seawater-tryptone $(1 / 2$ SWT) $2 \%$ agar plates (Boettcher \& Ruby 1990). The sea table had been exposed to continuously running, unfiltered natural seawater and substrata from piers in Pearl Harbor for more than 1 yr in ambient outdoor light prior to sampling. Bacterial strains that grew on the plates were further isolated until separated into single strains.
After isolation, single-strain bacteria were grown in liquid $1 / 2$ SWT to log phase, then stored in $15 \%$ glycerol at $-70^{\circ} \mathrm{C}$. Four strains, originally labeled KMB1, KMB2, KMB3 and KMB4 (for Kewalo Marine Lab Biofilm Species 1 to 4), were selected for settlement assays with larvae of Hydroides elegans and for 16S rRNA-gene sequence taxonomic analysis.

Molecular determination of bacterial identities with 16S rRNA gene sequencing and phylogenetic analysis. Genomic DNA from the 4 selected bacterial strains was extracted from $1 \mathrm{~d} 1 / 2$ SWT liquid cultures using CTAB (Sigma) and phenol/chloroform (Ausubel et al. 1999). Sequences coding for $16 \mathrm{~S}$ rRNA genes were amplified with a PCR Core System II kit (Promega). The respective forward and reverse oligonucleotide primers used were eubacterial 8F (AGA GTT TGA TCC TGG CTC AG) and 1492R (GGT TAC CTT GTT ACG ACT T) (Operon). The reaction mixture contained template DNA, $3 \mathrm{mM} \mathrm{MgCl}_{2}, 200 \mu \mathrm{M}$ deoxynucleotide triphosphate $\mathrm{mix}, 0.1 \mu \mathrm{M}$ of each primer, $1 \mathrm{X}$ buffer $(50 \mathrm{mM} \mathrm{KCl}, 10 \mathrm{mM}$ Tris- $\mathrm{HCl}$ [pH 9]), and $2.5 \mathrm{U} 100 \mathrm{\mu l}^{-1}$ Taq DNA polymerase. The PCR reaction tubes were incubated for $4 \mathrm{~min}$ at $94^{\circ} \mathrm{C}$ for denaturation, then subjected to 30 cycles consisting of denaturation at $94^{\circ} \mathrm{C}$ for $1.5 \mathrm{~min}$, annealing at $50^{\circ} \mathrm{C}$ for $1.5 \mathrm{~min}$ and primer extension at $72^{\circ} \mathrm{C}$ for $2 \mathrm{~min}$, followed by a final extension for $10 \mathrm{~min}$ at $72^{\circ} \mathrm{C}$. PCR products were cleaned with a QIAquick purification kit (Qiagen) and sent immediately to the Biotechnology Facility of the University of Hawaii at Manoa for sequencing.

Sequences were searched using the BLAST program of GenBank in the National Center for Biotechnology Information (NCBI) web site and by the Sequence Match program of the Ribosomal Database Project (RDP) web site for closely related sequences. Sequences were aligned using the SeqWeb 9 (Accelrys). Phylogenetic analyses and phylogenetic distances were calculated with the Jukes-Cantor model by MEGA 9 (Kumar et al. 1993). A phylogenetic tree was built using the neighbor-joining method with the program MEGA. The MEGA results were compared to those obtained with use of the program Phylip (Felsenstein 1993). Bacterial sequences selected for constructing the phylogenetic tree came from: (1) Cytophaga latercula (M58769), C. lytica (AB032510), Flexibacter maritimus (M64629) in the Cytophaga-FlavobacteriumBacteroides branch; and (2) Pseudoalteromonas luteoviolacea (X82144), P. atlantica (X82134), Escherichia coli (AB045731), Vibrio fischeri (X74702) and Bacillus subtilis (X60646) in the Proteobacteria branch (numbers in parentheses are GenBank nucleotide sequenceaccession numbers).

The molecular approaches described above allowed the assignment of each of the 4 bacterial strains to a 
genus and, in 2 cases, to a species. Strain KMB1 was found to have $99.8 \%$ sequence identity with the wellstudied biofilm bacterium Pseudoalteromonas luteoviolacea and is assigned to that species. Colonies of KMB1 also had the dark purplish-brown color typical of $P$. luteoviolacea. Further justification for this designation is presented in 'Results'.

Metamorphosis on four monospecific bacterial biofilms. Each of the 4 bacterial strains was grown in $1 / 2$ SWT for $1 \mathrm{~d}$ before being tested in settlement assays. Bacterial cells were first collected by centrifugation at $2500 \times g$ for $10 \mathrm{~min}$. Supernatants of each strain were reserved and filtered through a $0.2 \mu \mathrm{m}$ syringe filter to remove any remaining cells. Cells in pellets were resuspended in FSW and centrifuged again to remove any remaining culture media. Pellets were then resuspended in FSW and the cell density of the culture was determined by optical density at $600 \mathrm{~nm}$. Cell densities in all strains were then adjusted to approximately $10^{8}$ cells $\mathrm{ml}^{-1}$.

The adjusted cell suspensions were poured into plastic Petri dishes $\left(35 \times 10 \mathrm{~mm}\right.$, Falcon $\left.{ }^{\circledR}\right)$ and incubated for $1 \mathrm{~h}$ to allow the bacteria to attach to the surfaces. The suspensions were emptied from the dishes, which were then rinsed with FSW 3 times to remove unattached cells and refilled with FSW. At this point, approximately 50 competent larvae of Hydroides elegans were added to each dish. Another set of dishes was soaked for $1 \mathrm{~h}$ with the reserved cell-free supernatants from the bacterial cultures, rinsed 3 times as for all other treatments described above, and exposed to larvae to determine whether soluble products from each bacterial strain might adsorb to substrata and induce metamorphosis in $H$. elegans. Pieces of Vexar ${ }^{\circledR}$ plastic mesh (approximately $10 \times 20 \mathrm{~mm}$ ) that had been floated in an outdoor sea table with flowing, ambient seawater under natural illumination for at least $5 \mathrm{~d}$ to accumulate a natural biofilm were employed as positive controls to test for metamorphic competence of the larvae used in each experiment. Larvae were kept in dishes that had been incubated with either FSW or autoclaved $1 / 2$ SWT medium to test for levels of spontaneous metamorphosis (negative controls).

Five replicates of each treatment were used in all settlement-induction tests. The percentages of metamorphosing Hydroides elegans attached to the surfaces were determined after $24 \mathrm{~h}$. Data were evaluated with Wilcoxin's signed-ranks non-parametric test, using the probability value of $\mathrm{p}<0.05$ in a KruskalWallis chi-square approximation to indicate significant differences between treatments. A duplicate set of all the dishes described above was prepared and fixed in $2 \%$ formaldehyde after being rinsed with ASW. The fixed bacterial cells were stained with DAPI (Sigma) at $100 \mu \mathrm{g} \mathrm{ml}^{-1}$ in distilled water, and cell densities were determined by counting 5 fields of $1000 \mu^{2}$ on each of the 5 replicate dishes under an epifluorescence microscope. An analysis of variance (ANOVA) performed for each bacterial strain to test for differences among replicates was non-significant ( $p>0.10$ ), and therefore counts from the replicates for each strain were pooled for subsequent analyses. ANOVA was performed on the pooled counts to examine significance of differences in biofilm densities among the bacterial strains.

Metamorphosis on Pseudoalteromonas luteoviolacea at different cell densities. Preliminary experiments showed that, of the 4 bacterial strains tested, Pseudoalteromonas luteoviolacea (KMB1) induced metamorphosis most strongly in larvae of Hydroides elegans (see 'Results'). For that reason, P. luteoviolacea was selected to study the role of bacterial cell density in metamorphic induction of $H$. elegans. Cells from $1 \mathrm{~d}$ cultures of $P$. luteoviolacea were harvested, washed once by centrifugation $(2500 \times g, 10 \mathrm{~min})$, and resuspended in FSW at densities of $5 \times 10^{8}, 10^{8}, 5 \times 10^{7}, 10^{7}$ and $5 \times 10^{6}$ cells $\mathrm{ml}^{-1}$. These cell suspensions at different densities were then used to treat Petri dishes using the methods described above. Biofilmed pieces of plastic mesh were used as a positive control, and cellfree supernatants from bacterial cultures, uncultured medium and FSW served as negative controls. Approximately 50 larvae of $H$. elegans were added to each Petri dish and the number of metamorphosed individuals was counted after $24 \mathrm{~h}$. A duplicate set of the test dishes with each of the bacterial densities was prepared for use in bacterial counts at the same time as those exposed to larvae. After standing for $1 \mathrm{~h}$, the bacterial suspensions were emptied from the dishes, the dishes were rinsed with ASW, and the biofilms were fixed and stained as described above for determining bacterial densities. There was no apparent patchiness in the distribution of bacterial cells in the biofilms.

The effect of soluble bacterial products on metamorphosis of Hydroides elegans. An assay was designed to determine whether soluble products from Pseudoalteromonas luteoviolacea would induce metamorphosis in $H$. elegans. Petri dishes were inoculated with $1 \mathrm{~d}$ cultures of $P$. luteoviolacea for $1 \mathrm{~h}$ and then rinsed as described above. The dishes were refilled with FWS containing $20 \mu \mathrm{g} \mathrm{ml}^{-1}$ chloramphenicol and approximately 50 larvae were added to each one. The efficacy of chloramphenicol against $P$. luteoviolacea was tested by placing a $1 \mathrm{~cm}$ square of sterile filter paper soaked in chloramphenicol at the same concentration on a lawn of $P$. luteoviolacea and observing that a zone of inhibited bacterial growth appeared around the filter paper. Other assays demonstrated that chloramphenicol alone had no effect on normal metamorphosis of $H$. elegans. Natural biofilms on $\operatorname{Vexar}^{\circledR}$ were 
also tested for metamorphosis-inducing activity in the presence of $20 \mathrm{\mu g} \mathrm{ml}^{-1}$ chloramphenicol. Positive controls included natural biofilms and a biofilm composed only of $P$. luteoviolacea; negative controls included dishes inoculated with supernatant from a broth culture of $P$. luteoviolacea, $1 / 2$ SWT medium, FSW and $20 \mu \mathrm{g} \mathrm{ml}^{-1}$ chloramphenicol in FSW.

To determine whether dialyzable bacterial metabolites could induce settlement and metamorphosis in larvae of Hydroides elegans, $15 \mathrm{~cm}$ lengths of dialysis tubing (cut off = 12 to $14 \mathrm{kDa}$ ) were tied at one end, boiled in an aqueous solution of $2 \%$ sodium bicarbonate and $1 \mathrm{mM}$ EDTA for $10 \mathrm{~min}$, rinsed and then autoclaved in distilled water. Cells from a $24 \mathrm{~h}$ culture of Pseudoalteromonas luteoviolacea (KMB1) were collected by centrifugation at $2500 \times g$ for $10 \mathrm{~min}$, resuspended in FSW and centrifuged again to remove any remaining culture media. The pellet was then resuspended in FSW, and $10 \mathrm{ml}$ of the cell suspension were poured into each piece of autoclaved dialysis tubing before the open ends of the tubing were tied. Five pieces of dialysis tubing containing KMB1 cells were placed individually in $10 \mathrm{~cm}$ diameter acid-washed glass finger bowls filled with $\sim 200 \mathrm{ml} \mathrm{FSW}$, and approximately 200 competent larvae of $H$. elegans were added to each dish. Controls included dishes with tubing containing FSW only (negative control) or pieces of Vexar ${ }^{\circledR}$ plastic mesh (approximately $10 \times 20 \mathrm{~mm}$ ) which had been floated in flowing seawater for at least $5 \mathrm{~d}$ to accumulate a natural biofilm (positive control). The percentages of metamorphosed $H$. elegans attached to the surfaces of the dialysis tubing or Vexar were determined after $24 \mathrm{~h}$.

Bacterial EPS production and larval settlement. Six mucoid $(\mathrm{M}), \mathrm{EPS}^{+}$strains and 5 crenated $(\mathrm{C}), \mathrm{EPS}^{-}$ strains of Pseudoalteromonas atlantica were tested for their capacity to induce settlement of Hydroides elegans by the same methods described above. Because excess carbohydrate availability has been linked to production of more EPS material (Skillman et al. 1999), both $1 / 2$ SWT medium and a glucose-enriched medium $(1 / 2$ SWT containing $2 \%$ glucose) were used to produce bacterial test cultures. Bacterial cell densities in treatments were monitored with DAPI staining and epifluorescence microscopy as described above.

\section{RESULTS}

\section{Identification and phylogenetic analysis of the four bacterial strains by $16 \mathrm{~S}$ rDNA sequencing}

PCR amplification yielded nearly complete $16 \mathrm{~S}$ rDNA sequences for each of the 4 strains, including $1450 \mathrm{nt}$ from KMB1, 1441 nt from KMB2, 1445 nt from KMB3 and 1437 nt from KMB4. The 16S rDNA sequences group the 4 strains into 2 different phylogenetic branches. KMB1 grouped into the $\gamma$-Proteobacteria subdivision, with a sequence identity of $99.8 \%$ to Pseudoalteromonas luteoviolacea, and is therefore designated a strain of that species (Table 1). Sequences from the other 3 strains placed them in the CytophagaFlavobacterium-Bacteroides (CFB) subdivision. In the distance matrix constructed using 16S rDNA sequence phylogeny (Table 1), KMB2 was closest to Flexibacter maritimus with a $92.4 \%$ identity, and KMB3 was closest to Cytophaga latercula with an identity of $97.6 \%$. The sequence of KMB4 has a $99.9 \%$ identity to that of $C$. lytica, allowing assignment of KMB4 to that species.

The phylogenetic tree (Fig. 1) derived from the selected 16S rDNA sequences has 2 major branches,

Table 1. Pairwise distance matrix of 16S rRNA gene sequences using the Jukes-Cantor model. The table includes 13 species and 1291 nucleotides for each sequence. Sequences other than KMB1, KMB2, KMB3 and KMB4 were obtained from the GenBank Database

\begin{tabular}{|c|c|c|c|c|c|c|c|c|c|c|c|c|}
\hline & 1 & 2 & 3 & 4 & 5 & 6 & 7 & 8 & 9 & 10 & 11 & 12 \\
\hline \multicolumn{13}{|l|}{ 1. KMB2 } \\
\hline 2. Flexibacter maritimus & 0.076 & & & & & & & & & & & \\
\hline 3. Cytophaga fucicola & 0.123 & 0.123 & & & & & & & & & & \\
\hline 4. Cytophaga lytica & 0.121 & 0.123 & 0.014 & & & & & & & & & \\
\hline 5. KMB4 & 0.122 & 0.124 & 0.015 & 0.001 & & & & & & & & \\
\hline 6. Cytophaga latercula & 0.120 & 0.125 & 0.086 & 0.083 & 0.083 & & & & & & & \\
\hline 7. KMB3 & 0.125 & 0.130 & 0.085 & 0.086 & 0.087 & 0.024 & & & & & & \\
\hline 8. KMB1 & 0.310 & 0.320 & 0.328 & 0.335 & 0.336 & 0.330 & 0.324 & & & & & \\
\hline $\begin{array}{l}\text { 9. Pseudoalteromonas } \\
\text { luteoviolacea }\end{array}$ & 0.308 & 0.318 & 0.326 & 0.333 & 0.334 & 0.328 & 0.322 & 0.002 & & & & \\
\hline $\begin{array}{l}\text { 10. Pseudoalteromonas } \\
\text { atlantica }\end{array}$ & 0.306 & 0.316 & 0.333 & 0.340 & 0.341 & 0.335 & 0.332 & 0.031 & 0.032 & & & \\
\hline 11. Escherichia Coli & 0.326 & 0.335 & 0.352 & 0.359 & 0.360 & 0.345 & 0.339 & 0.123 & 0.124 & 0.123 & & \\
\hline 12. Vibrio fischeri & 0.328 & 0.330 & 0.340 & 0.340 & 0.341 & 0.347 & 0.349 & 0.118 & 0.116 & 0.115 & 0.114 & \\
\hline 13. Bacillus subtilis & 0.345 & 0.344 & 0.334 & 0.332 & 0.333 & 0.326 & 0.334 & 0.259 & 0.257 & 0.261 & 0.256 & 0.273 \\
\hline
\end{tabular}




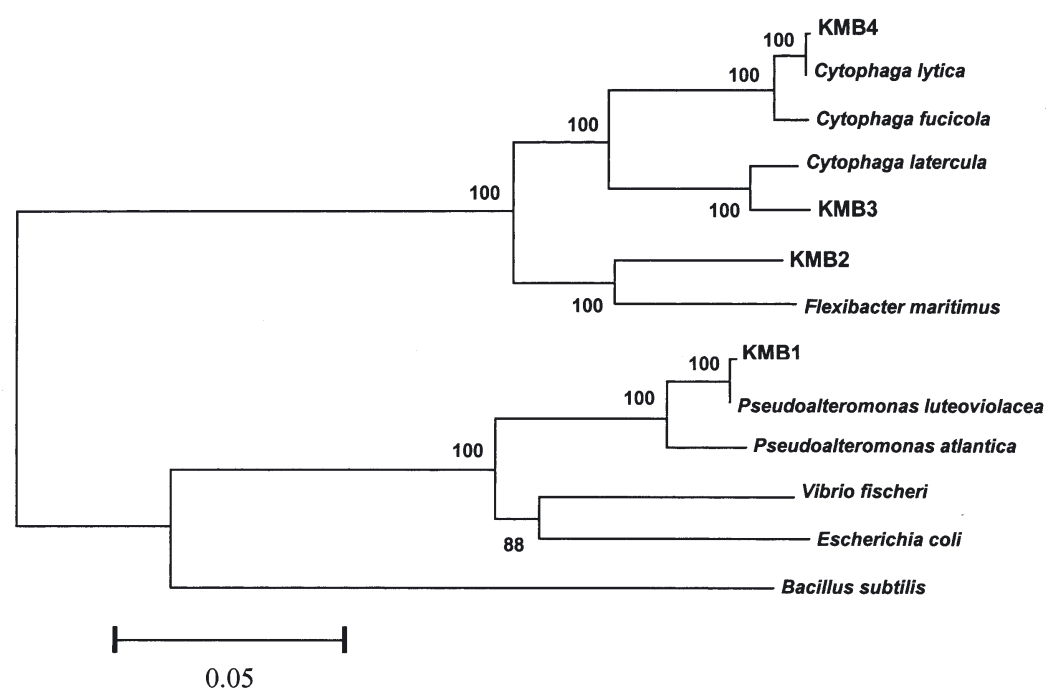

Fig. 1. Neighbor-joining phylogenetic tree (Jukes-Cantor model) of KMB1, KMB2, KMB3 and KMB4, their closely related species, and outgroups, based on $16 \mathrm{~S}$ rDNA sequences. Sequences other than the $4 \mathrm{KMB}$ strains were obtained from the GenBank Database. Numbers at each branch are bootstrap values. Genetic distances between strains are expressed as branch lengths

$82.4 \%$ of larvae to metamorphose. KMB3, an unidentified Cytophaga sp., induced only $7.2 \%$ metamorphosis, which was not significantly different ( $p>0.05$ ) from the negative controls. The low levels of metamorphosis induced by KMB2 were about equal to those in negative controls. None of the filter-sterilized supernatants induced metamorphosis, indicating that no soluble inductive factors smaller than 12 to $14 \mathrm{kDa}$ were released by inductive bacteria when in suspension and adsorbed to the plastic Petri dishes.

Examination after fluorescent staining of the bacterial cells on the Petri dishes in the above experiments revealed obvious differences. Cells of Pseudoalteromonas luteoviolacea were smaller and notably less abundant in the biofilm than the other 3 strains. Cell counts revealed that there were significant differences in cell densities on the Petri dishes between the strains

the upper one including the Cytophaga and Flexibacter species, and the lower one holding the Proteobacteria species, including species of Pseudoalteromonas. The genetic distance between KMB1 (Pseudoalteromonas luteoviolacea) and the 7 species in the upper branch averaged $32.6 \%$. P. luteoviolacea (KMB1) and C. lytica (KMB4), the 2 species that induced the most metamorphosis in larvae of Hydroides elegans, are separated by a genetic distance exceeding $33 \%$. On the other hand, $P$. atlantica, congeneric with and genetically differing from $P$. luteoviolacea by only $3.1 \%$, did not induce metamorphosis. This molecularphylogenetic analysis revealed that the inductive bacterial strains were not taxonomically more closely related to each other than they were to the noninductive strains.

\section{Metamorphosis on four single-strain bacterial biofilms}

Larvae of Hydroides elegans responded differently to biofilms composed of different bacterial strains (Fig. 2). In this comparison experiment, Pseudoalteromonas luteoviolacea, which had the strongest effect among the 4 strains, induced an average of $60.35 \%$ metamorphosis. Both P. luteoviolacea and Cytophaga lytica induced significantly $(p<0.05)$ greater percentages of metamorphosis than the negative controls (culture medium and FSW), but were less effective than the natural biofilm, which induced
(ANOVA, p $\ll 0.005$ ) (Fig. 3), although all 4 bacterial strains were inoculated at the same initial cell concentrations. The densities ranged from $10^{5}$ cells $\mathrm{mm}^{-2}$ in the dishes incubated with Cytophaga lytica to only $5.7 \times 10^{3}$ cells $\mathrm{mm}^{-2}$ in the biofilm of $P$. luteoviolacea. Strains KMB2 and KMB3, at densities of $4.05 \times 10^{4}$ and $6.99 \times 10^{4}$ cells $\mathrm{mm}^{-2}$, respectively, did not induce sig-

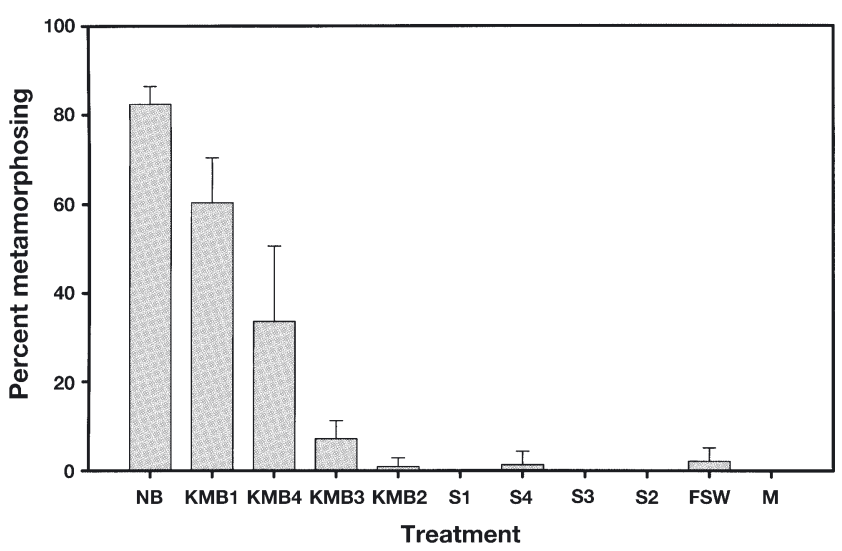

Fig. 2. Hydroides elegans. Induction of metamorphosis by mono-specific biofilms on plastic Petri dishes prepared from bacterial Strains KMB1, KMB2, KMB3 and KMB4. Controls include: (1) dishes similarly treated with filter-sterilized culture medium from each bacterial strain (S1, S2, S3 and S4); (2) natural biofilms (NB) allowed to accumulate on Vexar ${ }^{\circledR}$ mesh in flowing seawater and placed in a Petri dish of FSW; (3) untreated Petri dishes filled with filtered seawater (FSW); and (4) dishes rinsed with fresh culture medium (M). Bars represent mean percent of larvae that metamorphosed in $24 \mathrm{~h}+\mathrm{SD}$ ( $\mathrm{n}=5$ replicates per treatment) 


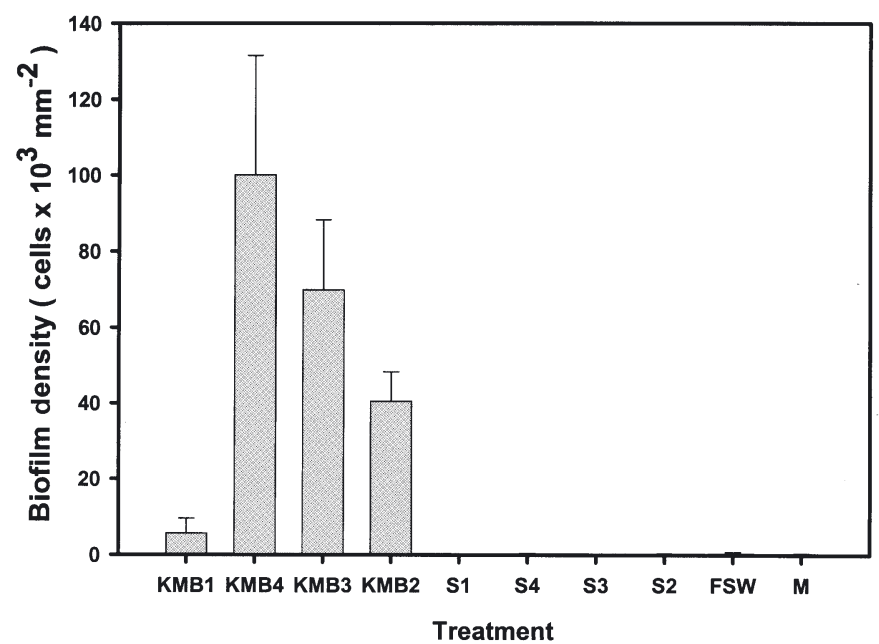

Fig. 3. Bacterial densities in single-species biofilms (see Fig. 2), counted under fluorescence microscopy after formalin fixation and DAPI staining. KMB1, KMB2, KMB3 and KMB4 are the bacterial strains studied; $\mathrm{S} 1$ to $\mathrm{S} 4$ are dishes treated with the supernatants from each strain, respectively; FSW and $\mathrm{M}$ are filtered seawater and culture-medium-only controls. Bars represent bacterial cell numbers $\times 10^{3} \mathrm{~mm}^{-2}+\mathrm{SD}(\mathrm{n}=25$, consisting of area counts per replicate and 5 replicate dishes per treatment; replicate effects were not significant, see 'Materials and methods')

nificant levels of metamorphosis (Fig. 2). No or very few bacteria were observed in the negative controls and the cell-free supernatants (Fig. 3).

\section{Effect of bacterial cell density on metamorphic induction}

Cell densities in the biofilms correlated well with cell densities in the inoculation cultures of Peudoalteromonas luteoviolacea, KMB1 (Fig. 4A). Biofilm cell densities varied between $10^{4}$ cells $\mathrm{mm}^{-2}$ in dishes inoculated at $10^{8}$ cells $\mathrm{ml}^{-1}$ and $2.8 \times 10^{4}$ cells $\mathrm{mm}^{-2}$ in dishes inoculated at $5 \times 10^{8}$ cells ml $\mathrm{m}^{-1}$. Percent metamorphosis in the larvae of Hydroides elegans correlated positively with bacterial cell densities in these biofilms (Fig. 4B). In these experiments, mean metamorphosis was $82.2 \%$ on the densest biofilm of $P$. luteoviolacea, a value as great as that observed on the biofilm developed in flowing seawater in a seasoned water table. The percentage fell to $38.9 \%$ at the second highest biofilm density $(10.02 \times$ $10^{3}$ cells $\mathrm{mm}^{-2}$ ). At the lowest biofilm densities tested, i.e. 1 to $2 \times 10^{3}$ cells $\mathrm{mm}^{-2}$, percentages of larvae that metamorphosed were not significantly different from the negative control (FSW). However, bacterial numbers, even in the densest biofilms of $P$. luteoviolacea, averaged only 28 cells $1000{\mu m^{-2}}^{-}$compared to
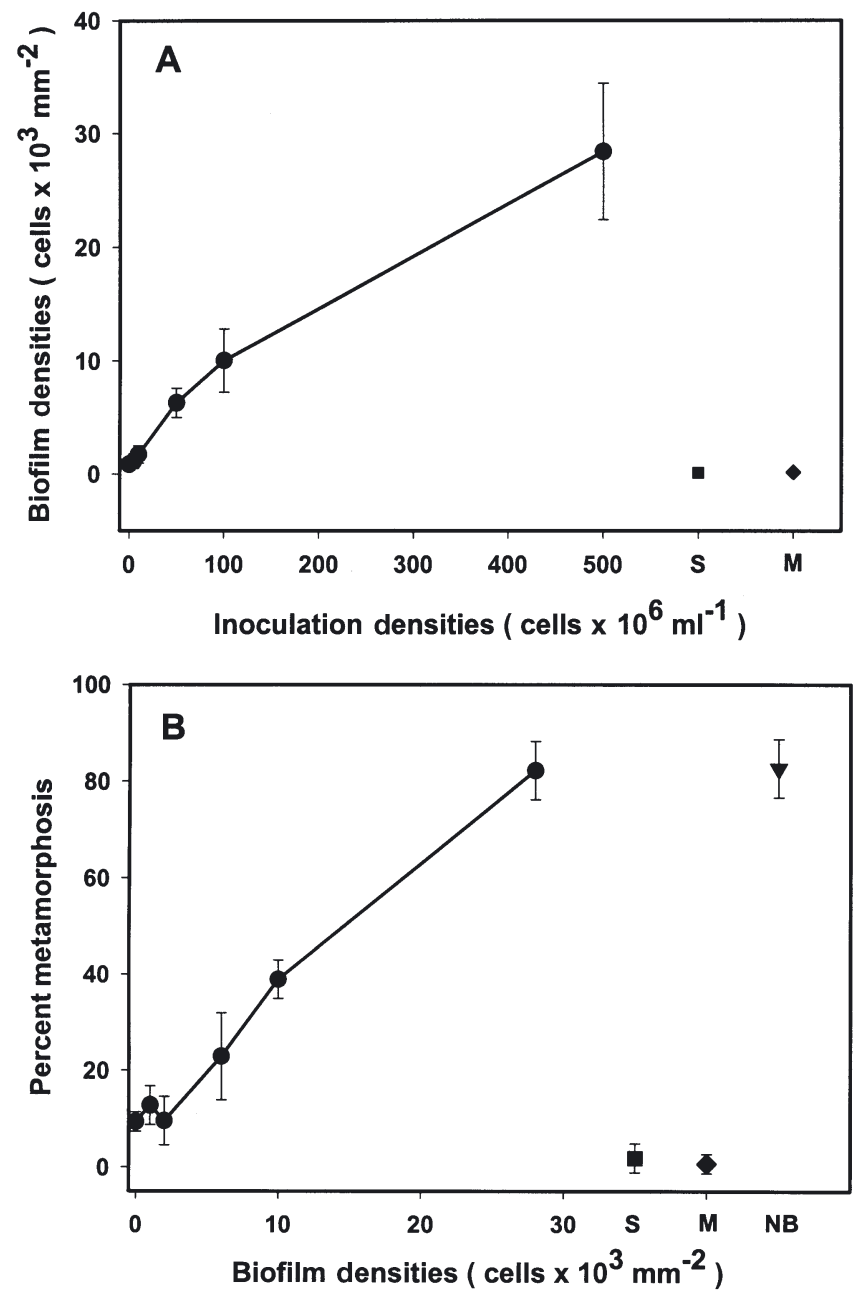

Fig. 4. (A) Pseudoalteromonas luteoviolacea. Cell densities in KMB1 biofilms inoculated for $1 \mathrm{~h}$ at 5 different broth culture densities. The culture supernatant was reserved from centrifugation, filtered through a $0.2 \mu \mathrm{m}$ filter to remove bacterial cells, and used for a control (S). Other controls: 0, filtered seawater only; $M$, autoclaved $1 / 2$ SWT medium. Cell densities $\pm \mathrm{SD}(\mathrm{n}=25$, consisting of 5 areas per replicate and 5 replicates per treatment) are shown. (B) Hydroides elegans. Induction of metamorphosis by the biofilms of KMB1 represented in Fig. 4A; bacterial densities in the biofilms were determined at the end of the experiment. Controls include: $\mathrm{NB}$, natural biofilm developed on $\operatorname{Vexar}^{\circledR}$ mesh in running seawater; FSW, $0.22 \mu \mathrm{m}$ filtered seawater; $M$, culture medium. Mean percentages of larvae that metamorphosed after $24 \mathrm{~h} \pm \mathrm{SD}(\mathrm{n}=5$ replicates per treatment) are shown

approximately 80 cells of many bacterial species per $1000 \mu^{-2}$ in a $3 \mathrm{~d}$ old sea table biofilm (Hadfield et al. 1994). Visual examination of these biofilms of $P$. luteoviolacea revealed that single or small clusters of bacterial cells were typically separated by spaces of 20 to $40 \mu \mathrm{m}$, or around 30 bacterial cell lengths. Biofilms formed by the other bacterial species were even and continuous. 


\section{Effect of soluble products on metamorphosis}

Percentages of metamorphosis induced by a biofilm composed only of Pseudoalteromonas luteoviolacea approached those on complex biofilms developed in the sea tables, and the inductive capacity of neither was significantly different with or without chloramphenicol in the seawater (Fig. 5). In clean dishes containing only FSW with chloramphenicol, the larvae swam energetically for $>24 \mathrm{~h}$, demonstrating that the antibiotic did not impact their health or activity patterns.

No larvae settled in glass dishes with dialysis tubing containing living cells of Pseudoalteromonas luteoviolacea (KMB1), suggesting either that 12 to $14 \mathrm{kDa}$ cutoff dialysis tubing is sufficient to block the diffusion of a soluble cue, or that the larvae must be in direct contact with the biofilm for the process of metamorphosis to be stimulated. The average percentage of larvae that metamorphosed in the positive controls was similar to that in other assays, indicating that the larvae used in this experiment were competent. In one instance, the dialysis tubing was inadvertently punctured during experimental setup, probably by the pipette tip when larvae were being introduced, and the puncture was not noted until the assays were

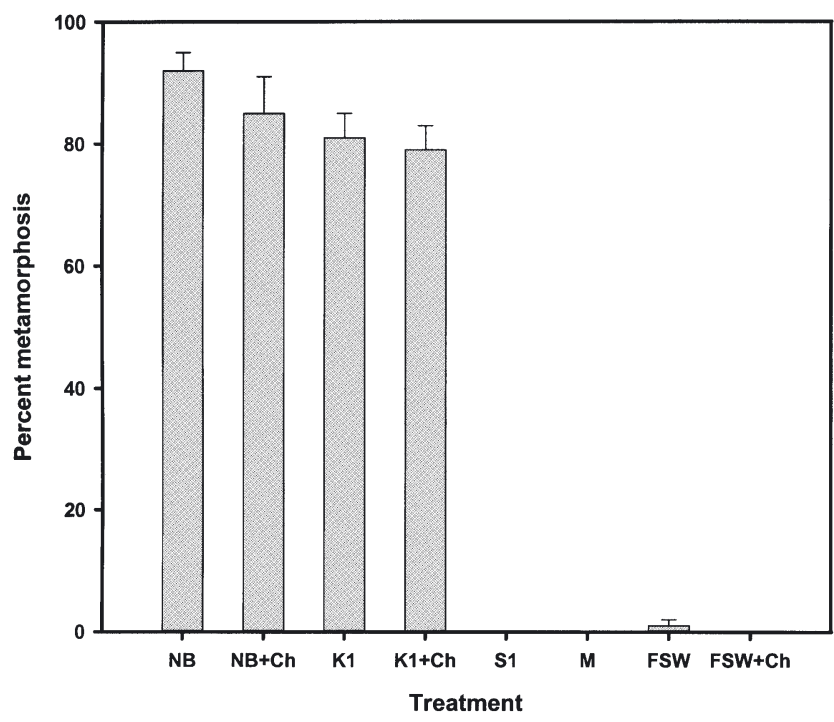

Fig. 5. Hydroides elegans. Induction of metamorphosis by biofilms of bacterial strain KMB1 (Pseudoalteromonas luteoviolacea) in the presence of $20 \mu \mathrm{g} \mathrm{ml}^{-1}$ chloramphenical. Treatments include NB, natural biofilm on Vexar ${ }^{\circledR}$ screen; $\mathrm{NB}+\mathrm{Ch}$, natural biofilm plus chloramphenicol in FSW; K1, biofilm of bacterial strain KMB1; $\mathrm{K} 1+\mathrm{Ch}$, biofilm of strain KMB1 plus chloramphenicol in FSW; $\mathrm{S} 1$, filtered supernatant from Strain KMB1; M, culture medium; FSW, filtered sea water only; FSW+Ch, FSW with chloramphenicol. Bars represent mean percent metamorphosed after $24 \mathrm{~h}+\mathrm{SD}(\mathrm{n}=5$ replicates per treatment) monitored after $24 \mathrm{~h}$. In this dish, nearly all of the larvae had entered the tubing through the hole and metamorphosed within it, in the presence of the living bacterial cells.

\section{EPS production and larval settlement}

Larvae of Hydroides elegans were not induced to settle or metamorphose by biofilms consisting of either the $\mathrm{EPS}^{+}$(mucoid, M) or EPS- (crenated, C) strains of Pseudoalteromonas atlantica tested, regardless of whether the strains were cultured in $1 / 2$ SWT or in glucose-enriched $1 / 2$ SWT. Cell densities in biofilms of both the M- and the C-strains were comparable to those of $P$. luteoviolacea that induced high percentages of metamorphosis. There were also no differences in biofilm cell densities attained by $\mathrm{M}$ - and C-types under the experimental conditions presented here.

\section{DISCUSSION}

\section{Phylogenetic analysis of biofilm bacterial strains using 16S rRNA gene sequences}

16S rRNA gene divergence is used extensively for bacterial phylogenetic analysis (Woese 1987). With a sequence similarity $>99 \%$, KMB1 is very likely Pseudoalteromonas luteoviolacea (Seguritan \& Rohwer 2001). Strain KMB4 had sufficient $16 \mathrm{~S}$ rDNA sequence similarity with Cytophaga lytica $(99.9 \%)$ to be assigned to that species. Species in the genus Cytophaga are known for their production of EPS and extracellular enzymes that digest macromolecules such as cellulose and chitin (Reichenbach 1984). C. latercula has been shown to have algicidal activities (Maeda et al. 1998), which might protect this biofilm bacterium from overgrowth by fouling algae. Such differences in the metabolic activities of these biofilm bacteria may provide important characters that larvae utilize as settlement cues.

Of the biofilm bacterial strains studied here, both Pseudoalteromonas luteoviolacea (KMB1) and Cytophaga lytica (KMB4) demonstrated positive metamorphosis-inducing activity for larvae of Hydroides elegans, despite a greater than $30 \%$ phylogenetic distance between the bacterial species. In addition, congeners of these 2 inductive species $-P$. atlantica and KMB3, a Cytophaga sp. - lacked metamorphosisinducing activity for $H$. elegans. For larvae of $H$. elegans, induction of metamorphosis by biofilm bacteria shows no correlation with bacterial phylogenetic relationships. Lau \& Qian (2002) drew similar conclusions, based on bacterial identifications at the generic level. 


\section{Effect of biofilm bacterial density on settlement of Hydroides elegans}

It was previously shown that the strength of metamorphic induction by natural, multi-species biofilms correlates with the bacterial cell densities in the biofilms (Hadfield et al. 1994, Unabia \& Hadfield 1999). The present study demonstrated that this is also true among films composed of single bacterial species. Importantly, it was found that some bacterial species are strongly inductive at densities much lower than those in natural biofilms or in biofilms composed of single bacterial species that are only weakly or non-inductive. Low-density mono-specific biofilms of Pseudoalteromonas luteoviolacea (KMB1) induced larval settlement of Hydroides elegans at levels approaching those of natural biofilms. Biofilms composed of either Strain KMB2 or KMB3 did not induce metamorphosis even when cell densities were 7 to 12 times higher than those of P. luteoviolacea. Such specificity has been found in other studies of bacterial induction of metamorphosis of $H$. elegans (Unabia \& Hadfield 1999, Lau \& Qian 2001, 2002).

The settlement-inducing activity of a weakly inducing bacterial species (e.g. Cytophaga lytica) cannot be made as strong as a good inducer (Pseudoalteromonas luteoviolacea) even by a nearly 20 -fold greater density. These data strongly suggest that induction of settlement in larvae of Hydroides elegans is due to specific chemical characteristics of $P$. luteoviolacea. Lower percentages of larvae are induced to settle by a moiety present in some other bacteria that may be related, but not chemically identical, to the inductive factor of $P$. luteoviolacea. In fact, the low densities of $P$. luteoviolacea present on surfaces that were highly inductive of larval settlement raises the question as to whether it is indeed a 'film'. For larvae of $H$. elegans, it may be that contact frequency with scattered but strongly inductive bacterial cells during a phase of substratum exploration is more important than continuous contact with a complex layer of exopolymers secreted by the bacterial cells that form a film.

It was recently demonstrated that wild type and a yellow-pigmented mutant of Pseudoalteromonas tunicata repel larvae - or at least do not induce settlementwhereas purple and white mutants of the same species induce settlement of a variety of marine fouling species, including Hydroides elegans (Egan et al. 2002). This observation demonstrates even greater discrimination by these larvae, which we found capable of distinguishing between congeneric bacterial species.

\section{Effect of soluble products on metamorphosis}

Soluble products from Pseudoalteromonas luteoviolacea that can adsorb to clean surfaces do not appear to play a role in inducing larval settlement and metamorphosis of Hydroides elegans. Settlement did not occur when larvae were placed in dishes that had been conditioned with filtered, cell-free media from bacterial cultures that induced larval settlement when grown in a biofilm. However, it should be noted that bacteria in a planktonic phase - as in broth culture - may not secrete the same products that they do when in a biofilm (Costerton 1995). Furthermore, the inductive activity of neither natural biofilms nor biofilms composed of only $P$. luteoviolacea was affected when their cellular physiological activities were inhibited by the antibiotic chloramphenicol. Additionally, P. luteoviolacea did not induce larval settlement and metamorphosis in glass dishes when the bacterial culture was contained within a dialysis membrane. In 1 or 2 instances where the dialysis tubing ruptured during set-up of this experiment, larvae settled abundantly on the dialysis membrane, indicating that they are not averse to this substratum and that biofilms will develop on it. As noted previously, metamorphosed juveniles were also found within ruptured dialysis tubing that held suspended cells of $P$. luteoviolacea. Thus, all of the evidence reported here supports the hypothesis that the metamorphic cue from $P$. luteoviolacea is an insoluble surface-bound molecule(s), perhaps part of a secreted exopolymer.

\section{Bacterial EPS production and larval settlement}

EPS have been suggested to induce metamorphosis in marine invertebrates. Szewzyk et al. (1991) demonstrated that a major EPS secreted into a slime layer by a marine Pseudomonas sp. (Strain S9) was important for attachment of larvae of the ascidian Ciona intestinalis. Inhibition of production of a peripheral EPS by chloramphenicol caused a decrease in the number of ascidian larvae that attached to the substratum. The attachment rate was also reduced when the larvae were exposed to a transposon-generated mutant that was deficient in releasing the peripheral EPS.

Mitchell \& Kirchman (1984) and Maki \& Mitchell (1985) presented evidence that larvae of another small tube-dwelling polychaete, Janua brasiliensis, are stimulated to settle and metamorphose by extracellular polymers of biofilm bacteria, such as Pseudomonas marina, that vary in quality and quantity as a function of physiology and age of the bacteria. The authors concluded that lectins on the larvae bind to a D-glucosecontaining extracellular molecule in the bacterial EPS, resulting in a settlement signal for the larvae. A role for biofilms and bacterial products in settlement has been reported for larvae belonging to at least 10 different invertebrate phyla (Hadfield \& Paul 2001). 
The role of bacterial exopolymers in inducing settlement of larvae of Hydroides elegans was further examined using mutants of Pseudoalteromonas atlantica, a common biofilm bacterium found in coastal areas of both the Atlantic and the Pacific Oceans. However, neither the $\mathrm{EPS}^{+}$nor $\mathrm{EPS}^{-}$strains of $P$. atlantica induced larval settlement of $H$. elegans, regardless of whether the bacteria were cultured in $1 / 2$ SWT or in a medium enriched with glucose $(1 / 2$ SWT plus $2 \%$ glucose) to enhance EPS production. Both $\mathrm{EPS}^{+}$and EPS $^{-}$mutants of $P$. atlantica have been shown to form effective biofilms (Corpe et al. 1975). Clearly, $P$. atlantica lacks some component that is critical to settlement induction for $H$. elegans. It would be useful to find EPS-lacking mutants of $P$. luteoviolacea to address whether EPS may play a role in settlement induction.

Holmström et al. (2002) reported that a biofilm of Pseudoalteromonas luteoviolacea inhibited settlement by larvae of Hydroides elegans, compared to numbers settling in dishes supposedly lacking biofilms. However, in our experience, larvae of $H$. elegans will not settle in the absence of marine biofilms, and the duration of the assays used by Holmström et al. (2002)$2 \mathrm{~d}$-is sufficient for development of an inductive biofilm from bacteria introduced with the larval cultures, which cannot be established axenically. This may explain why the untreated controls of Holmström et al. (2002) produced $>50 \%$ of larval settlement versus about $40 \%$ settlement when $P$. luteoviolacea was present. Additionally, it is possible that differences between the strain of $P$. luteoviolacea from Australia tested by Holmström et al. (2002) and the Hawaiian strain produced different combinations of extracellular compounds (Holmström \& Kjelleberg 1999), and thus had very different effects on larval settlement of $H$. elegans. Divergent inductive capacities between unidentified species of Pseudoalteromonas from Hong Kong were reported by Lau \& Qian (2002).

\section{Advantages for larvae to settle on bacterial biofilms}

Because bacterial biofilms modify the properties of the substratum and may change with environmental conditions, the ability for marine invertebrate larvae to use specific biofilm bacteria as settlement cues implies positive selection for certain characteristics on surfaces which are suitable for adult survival (Burke 1983). Hydroides elegans is typically among the first macroinvertebrates to colonize a new surface in Pearl Harbor, Hawaii, and is often overgrown by ascidians and sponges after a few months (Holm et al. 2000). Thus, it may be adaptively important for larvae of $H$. elegans to respond to bacteria in newly formed biofilms that represent open spaces, so that the competition potential between adult $H$. elegans and other macroorganisms is reduced (Unabia \& Hadfield 1999).

Bacterial biofilms are structured communities composed of cells of many species, plus the surrounding extracellular polymeric matrix produced by these cells (Costerton et al. 1999). The development of marine biofilms is a constantly evolving process that includes microbial colonization, modification of the substrata and succession of different physiological groups. Spatial and temporal heterogeneity exists within microscale environmental characteristics in, for example, the species distribution, the presence of extracellular enzymes and the availability of organic materials (Meyer-Reil 1994). A mature bacterial biofilm represents an organized community that performs a variety of different functions such as defense, cell-cell communication and sequestering of nutrients (Costerton et al. 1999). For all of these reasons, marine biofilms are a major challenge to microbial ecologists (Meyer-Reil 1994). A major gap in our understanding of biofouling processes concerns the physical and/or chemical nature of the active component(s) that settlementinductive bacterial biofilms have in common. Data presented here reveal that the inductive capacity does not correlate with phylogenetic relationships among bacteria, and thus that the inductive substances are not limited to a single group of bacteria. Because the inductive activity of Pseudoalteromonas luteoviolacea was comparable to that of natural, multi-species biofilms, even at low cell densities, this bacterial species can be used as a model for isolating the active products. Additionally, DNA probes can be made from the $16 \mathrm{~S}$ rDNA sequence of $P$. luteoviolacea for in situ hybridization with biofilms developed in the field to determine the abundance of this bacterial species in natural habitats of Hydroides elegans.

Harder et al. (2002) have recently provided evidence that benthic diatoms, common components of native biofilms, induce settlement of larval Hydroides elegans. Although bacteria were present among the attached diatoms, the authors' experiments appear to support the supposition that the diatoms were the inductive entity. If further research bears this out, it will make the chemical identity of the settlementinductive moiety even more intriguing; do 2 phylogenetically distant organisms, bacteria and diatoms, produce the same substance, or are nectochaete larvae of $H$. elegans adapted to use more than 1 signal from appropriate settlement environments? If the latter is true, are multiple membrane receptors involved (see Holm et al. 1998)?

Acknowledgements. The authors are grateful to E. G. Ruby for advice on the research approaches and excellent constructive criticism of this manuscript. R. A. Kinzie also pro- 
vided useful suggestions for the project. C. Unabia assisted in many ways in our initial efforts to isolate and culture biofilm bacteria. D. H. Bartlett of Scripps Institution of Oceanography provided cultures of Pseudoalteromonas atlantica, which were critically important to some of our results. We also thank B. Nedved for essential help to S.H. with microscopy and microphotography, and others in the Hadfield laboratory for support in many different parts of this effort. Four anonymous reviewers provided useful criticism of the submitted draft of this paper. This research was supported in part by grants to M.G.H. from the National Science Foundation (OCE-9907545) and the Office of Naval Research (N0014-95-0196).

\section{LITERATURE CITED}

Akagawa-Matsushita M, Matsuo M, Koga Y, Yamasato K (1992) Alteromonas atlantica sp. nov. and Alteromonas carrageenovora sp. nov., bacteria that decompose algal polysaccharides. Int J Syst Bacteriol 42:621-627

Ausubel FM, Brent R, Kingston RE, Moore DD and 6 others (eds) (1999) Current protocols in molecular biology, Vol I. John Wiley \& Sons, New York

Bartlett DH, Silverman M (1989) Nucleotide sequence of IS492, a novel insertion sequence causing variation in extracellular polysaccharide production in the marine bacterium Pseudomonas atlantica. J Bacteriol 171: 1763-1766

Bartlett DH, Wright ME, Silverman M (1988) Variable expression of extracellular polysaccharide in the marine bacterium Pseudomonas atlantica is controlled by genome rearrangement. Proc Natl Acad Sci USA 85:3923-3927

Boettcher KJ, Ruby EG (1990) Depressed light emission by symbiotic Vibrio fisheri of the sepiolid Euprymna scolopes. J Bacteriol 172:3701-3706

Burke RD (1983) The induction of metamorphosis of marine invertebrate larvae: stimulus and response. Can J Zool 61: 1701-1719

Carpizo-Ituarte E, Hadfield MG (1998) Stimulation of metamorphosis in the polychaete Hydroides elegans Haswell (Serpulidae). Biol Bull 194:4-24

Chia FS, Rice ME (1978) Settlement and metamorphosis of marine invertebrate larvae. Elsevier North-Holland, New York

Corpe WA, Matsuuchi L, Armbruster B (1976) Secretion of adhesive polymers and attachment of marine bacteria to surfaces. In: Sharpley JM, Kaplan AM (eds) Proc 3rd Int Biodegradation Symp. Applied Sciences Publisher, London, p 433-442

Costerton JW (1995) Overview of microbial biofilms. J Ind Microbiol 15:137-140

Costerton JW, Stewart PS, Greenberg EP (1999) Bacterial biofilms: a common cause of persistent infections. Science 284:1318-1322

Crisp D (1974) Factors influencing the settlement of marine invertebrate larvae. In: Grant P, Mackie A (eds) Chemoreception in marine organisms. Academic Press, New York, p 177-265

Decho A (1990) Microbial exopolymer secretions in ocean environments: their role(s) in food webs and marine processes. Oceanogr Mar Biol Annu Rev 28:73-153

Egan S, James S, Holmström C, Kjelleberg S (2002) Correlation between pigmentation and antifouling compounds produced by Pseudomonas tunicata. Environ Microbiol 4: $433-442$

Felsenstein J (1993) PHYLIP (Phylogeny Inference Package) version 3.5c. Distributed by the author. Department of
Genetics, University of Washington, Seattle

Fitt WK, Coon SL, Walch M, Weiner RM, Colwell RR, Bonar DB (1990) Settlement behavior and metamorphosis of oyster larvae (Crassostrea gigas) in response to bacterial supernatants. Mar Biol 106:389-394

Hadfield MG (1998) The D P Wilson Lecture: research on settlement and metamorphosis of marine invertebrate larvae: past, present and future. Biofouling 12:9-29

Hadfield MG (2000) Why and how marine-invertebrate larvae metamorphose so fast. Semin Cell Dev Biol 11:437-443

Hadfield MG, Paul VJ (2001) Natural chemical cues for the settlement and metamorphosis of marine invertebrate larvae. In: McClintock JG, Baker BJ (eds) Marine chemical ecology. CRC Press, Boca Raton, FL, p 431-461

Hadfield MG, Strathmann MF (1996) Variability, flexibility and plasticity in life histories of marine invertebrates. Oceanol Acta 19:323-334

Hadfield MG, Unabia CC, Smith CM, Michael TM (1994) Settlement preferences of the ubiquitous fouler Hydroides elegans. In: Thompson MF, Nagabhushanam R, Sarojini $\mathrm{R}$, Fingerman $\mathrm{M}$ (eds) Recent developments in biofouling control. Oxford and IBH, New Delhi, p 65-74

Hamer JP, Walker G, Latchford JW (2001) Settlement of Pomatoceros lamarkii (Serpulidae) larvae on biofilmed surfaces and the effect of aerial drying. J Exp Mar Biol Ecol 260:113-131

Harder T, Lam C, Qian PY (2002) Induction of larval settlement in the polychaete Hydroides elegans by marine biofilms: an investigation of monospecific diatom films as settlement cues. Mar Ecol Prog Ser 229:105-112

Hofmann D, Fitt W, Fleck J (1996) Checkpoints in the lifecycle of Cassiopea spp.: control of metagenesis and metamorphosis in a tropical jellyfish. Int J Dev Biol 40:331-338

Holm E, Nedved B, Carpizo-Ituarte E, Hadfield MG (1998) Metamorphic-signal transduction in Hydroides elegans Haswell (Polychaeta: Serpulidae) is not mediated by a G protein. Biol Bull 195:21-29

Holm ER, Nedved BT, Phillips N, Deangelis KL, Hadfield MG, Smith C (2000) Temporal and spatial variation in the fouling of silicone coatings in Pearl Harbor, Hawaii. Biofouling 15:95-107

Holmström C, Kjelleberg S (1999) Marine Pseudoalteromonas species are associated with higher organisms and produce biologically active agents. FEMS Microbiol Ecol 30: 285-293

Holmström C, Egan S, Franks A, McCloy S, Kjelleberg S (2002) Antifouling activities expressed by marine surface associated Pseudoalteromonas species. FEMS Microbiol Ecol 41:47-58

Johnson C, Sutton D (1994) Bacteria on the surface of crustose coralline algae induce metamorphosis of the crown-ofthorns starfish Acanthaster planci. Mar Biol 120:305-310

Kirchman D, Graham S, Reish D, Mitchell R (1982) Bacteria induce settlement and metamorphosis of Janua (Dexiospira) brasiliensis Grube (Polychaeta: Spirorbidae). J Exp Mar Biol Ecol 56:153-163

Kumar S, Tamura K, Nei M (1993) MEGA: Molecular Evolutionary Genetics Analysis, version 1.01. The Pennsylvania State University, University Park

Lau SCK, Qian PY (2001) Larval settlement in the serpulid polychaete Hydroides elegans in response to bacterial films: and investigation of the nature of putative larval settlement cue. Mar Biol 138:321-328

Lau SCK, Qian PY (2002) Bioactivity of bacterial strains isolated from marine biofilms in Hong Kong waters for the induction of larval settlement in the marine polychaete Hydroides elegans. Mar Ecol Prog Ser 226:301-310 
Maeda T, Murakami M, Ohsugi S, Furushita M, Mitsutani A, Shiba T (1998) Perspectives of the development of 16S rDNA probe specific for algicidal and/or algal-lytic gliding bacteria. Fish Sci 64:861-865

Maki JS, Mitchell R (1985) Involvement of lectins in the settlement and metamorphosis of marine invertebrate larvae. Bull Mar Sci 37:675-683

Maki JS, Rittschof, D, Schmidt AR, Snyder AG, Mitchell R (1989) Factors controlling attachment of bryozoan larvae: a comparison of bacterial films and unfilmed surfaces. Biol Bull 177:295-302

Meyer-Reil L (1994) Microbial life in sedimentary biofilms the challenge to microbial ecologists. Mar Ecol Prog Ser 112:303-311

Mitchell R, Kirchman D (1984). The microbial ecology of marine surfaces. In: Costlow JD, Tipper RC (eds) Marine biodeterioration: an interdisciplinary study. Naval Institute Press, Annapolis, MD, p 49-58

Neal AL, Yule AB (1994) The interaction between Elminius modestus Darwin cyprids and biofilms of Deleya marina NCMB 1877. J Exp Mar Biol Ecol 176:127-139

Negri AP, Webster NS, Hill RT, Heyward AJ (2001) Metamorphosis of broadcast spawning corals in response to bacteria isolated from crustose algae. Mar Ecol Prog Ser 223: 121-131

Parsons GJ, Dadswell MJ, Roff JC (1993) Influence of biofilm on settlement of sea scallop, Placopecten magellanicus (Gmelin, 1791), in Passamaquoddy Bay, New Brunswick, Canada. J Shellfish Res 12:279-283

Pawlik JR (1992) Chemical ecology of the settlement of benthic marine invertebrates. Oceanogr Mar Biol Annu Rev 30:273-335

Reichenbach H (1984) Genus I. Cytophaga Winogradsky 1929, 577, (AL) emend. In: Staley JT, Bryant MP, Pfenning N, Holt JG (eds) Bergey's manual of systematic bacteriology, Vol 3. Williams \& Wilkins, Baltimore, p 2015-2050

Editorial responsibility: Charles Birkeland (Contributing Editor), Honolulu, Hawaii, USA
Satuito CG, Natoyama K, Yamazaki M, Fusetani N (1995) Induction of attachment and metamorphosis of laboratory cultured mussel Mytilus edulis galloprovincialis larvae by microbial film. Fish Sci 61:223-227

Seguritan V, Rohwer F (2001) FastGroup: a program to dereplicate libraries of $16 \mathrm{~S}$ rDNA sequences. BMC Bioinformatics 2(1):9

Skillman LC, Sutherland IW, Jones MV (1999) The role of exopolysaccharides in dual species biofilm development. In: Dennis PJ, Godfree AF, Stewart-Tull DES (eds) Aquatic microbiology: Society for Applied Microbiology Symposium Series 28. Blackwell Scientific Publications, Oxford, p 13-18

Steinberg PD, de Nys R, Kjelleberg S (2001) Chemical mediation of surface colonization. In: McClintock JB, Baker BJ (eds) Marine chemical ecology. CRC Press, Boca Raton, FL, p 355-387

Szewzyk U, Holmström C, Wrangstadh M, Samuelsson M, Maki J, Kjelleberg S (1991) Relevance of the exopolysaccharide of marine Pseudomonas sp. strain S9 for the attachment of Ciona intestinalis larvae. Mar Ecol Prog Ser 75:259-265

Unabia C, Hadfield MG (1999) The role of bacteria in larval settlement and metamorphosis of the polychaete Hydroides elegans. Mar Biol 133:55-64

Walters LJ, Hadfield MG, del Carmen KA (1997) The importance of larval choice and hydrodynamics in creating aggregations of Hydroides elegans (Polychaeta: Serpulidae). Invertebr Biol 116:102-114

Wieczorek SK, Clare AS, Todd CD (1995) Inhibitory and facilitatory effects of microbial films on settlement of Balanus amphitrite larvae. Mar Ecol Prog Ser 119:221-228

Woese CR (1987) Bacterial evolution. Microbiol Rev 51: 221-271

ZoBell C, Allen E (1935) The significance of marine bacteria in the fouling of submerged surfaces. J Bacteriol 29:239-251

Submitted: November 4, 2002; Accepted: June 16, 2003

Proofs received from author(s): September 9, 2003 